\title{
Influence of shellfish farming activities on the biogeochemical composition of the water column in Thau lagoon
}

\author{
Philippe Souchu ${ }^{1, *}$, André Vaquer ${ }^{2}$, Yves Collos $^{2}$, Sonia Landrein ${ }^{1}$, \\ Jean-Marc Deslous-Paoli ${ }^{1}$, Bertrand Bibent ${ }^{2}$ \\ ${ }^{1}$ Laboratoire Côtier DEL, IFREMER, BP 171 Avenue Jean Monnet, 34203 Sète, Cedex, France \\ ${ }^{2}$ Laboratoire Ecosystèmes Lagunaires (ERS 2011 CNRS), Université de Montpellier CC093, 34095 Montpellier, Cedex 5, France
}

\begin{abstract}
Thau lagoon is a Mediterranean shellfish ecosystem with large biomasses of oysters growing in waters with high residence time due to low tidal ranges. The influence of filter feeders (oysters and their epibiota) on the spatial distribution of particulate and dissolved compounds in the water column of Thau lagoon was studied through its variation with time. In 1991/1992, daily variations were investigated in pens, corridors and outside shellfish farming zones for nutrients, chlorophyll $a$ and primary production. Salinity, dissolved oxygen, nutrients, organic matter and chlorophyll a were also monitored in surface waters inside and outside shellfish farming zones each week from January 1993 to March 1994. The presence of shellfish farms led to a decrease by only a few percent of oxygen concentrations in their vicinity, but the mean $( \pm \mathrm{SE})$ deficits of chlorophyll $a$ and POC concentrations were $44 \pm 4 \%$ and $26 \pm 9 \%$ respectively in the eastern zone $(8 \mathrm{~m})$. The shift induced by filter feeders in phytoplankton composition favoured picophytoplankton with higher growth rates. But the summer increase in phytoplankton growth rate was stronger than the positive feedback due to filter feeder filtration. Summer was determinant for the growth of oysters owing to enhanced regenerated primary production. During this period, filter feeders were not food limited, while they tended to control phytoplankton biomasses and production the rest of the year. The nutrient excess in shellfish farming zones was highly significant, with increases of $73 \pm 16,36 \pm 12$ and $19 \pm 8 \%$ for ammonia, phosphates and silicate respectively in the eastern zone. In the western zone, the nutrient excess was less strong by half for ammonia and phosphate, because the lower depth (4 m) allows light to reach the bottom and enables benthic macroflora to grow on nutrients of benthic origin. The decline of phytoplankton biomasses in shellfish farms induced a decrease in the nutrient demand, especially for ammonia. This situation was likely to favour nitrification, which led during autumn to higher nitrate concentrations within shellfish farming zones than outside. Therefore, filter feeders were able to alter the dominant biogeochemical process in the water column by stimulating nitrification.
\end{abstract}

KEY WORDS: Suspension-feeding bivalves $\cdot$ Phytoplankton · Nutrient cycling $\cdot$ Carrying capacity · Thau lagoon

Resale or republication not permitted without written consent of the publisher

\section{INTRODUCTION}

The influence of filter feeders on their ecosystem has been principally studied through the biogeochemical cycles of carbon (Hawkins \& Bayne 1985, Rodhouse \&

*E-mail: psouchu@ifremer.fr
Roden 1987), nitrogen (Jordan \& Valiela 1982, Kaspar et al. 1985) and phosphorus (Kuenzler 1961). Filter feeders are efficient vehicles of particulate matter from the water column to sediments by filtration coupled with biodeposition (Kautsky \& Evans 1987), which leads to the accumulation of organic matter in sediments and the enhancement of benthic fluxes of nutri- 
ents (Sornin et al. 1986, 1990). Direct release of nutrients in the water column by excretion from reared filter feeders and their epibiota is also an important pathway for remineralisation (Dame et al. 1985). Consequently, shellfish farming areas act as sinks of particulate matter and sources of nutrients for the water column (Dame et al. 1989). Infact, the biogeochemical composition of waters has not been seen to vary significantly between the vicinity of extensive shellfish farming areas and outside (Kaspar et al. 1985, Souchu et al. 1991). In contrast to the shellfish farming areas of the Atlantic coast, the Thau lagoon is characterised by a lack of tides and sediment resuspension, and the oysters are suspended on ropes in the water column rather than being on or slightly above the sediment. In such ecosystems carrying intensive shellfish farming activities, the depletion of the chlorophyll a concentration in shellfish farming zones (Tournier \& Pichot 1985, Jarry et al. 1990) was a first indication of a significant shift in the biogeochemical cycles of elements, due to the presence of filter feeders. Early shellfish farms have been installed for almost a century in this ecosystem. However, no study focused on the ecological impacts of shellfish farming activities has been undertaken. The present study, based on a 3 yr programme, reports on the influence of filter feeders on the spatial distribution of particulate and dissolved compounds in the water column of Thau lagoon through its variation with time (season and day).

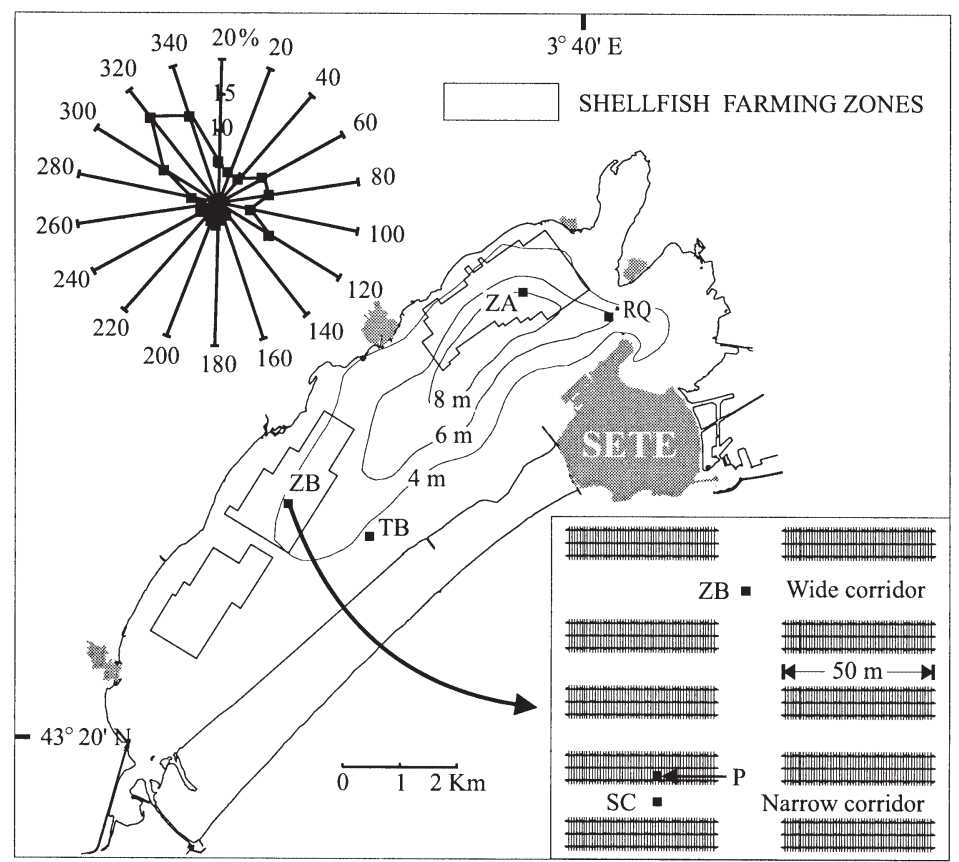

Fig. 1. Location of the sampling stations in Thau lagoon and distribution of winds (\%) on the compass dial. Inset shows locations of Stns ZB, P and $\mathrm{SC}$ among oyster pens. Stn ZA is situated in a wide corridor

\section{MATERIALS AND METHODS}

Thau lagoon is located on the French Mediterranean coast (Fig. 1). The 3 shellfish farming zones cover $18 \%$ of the total area with intensive activities (40 oysters Crassostrea gigas per $\mathrm{m}^{2}$ of shellfish farming zone for a standing stock of $25000 \mathrm{t}$ of oysters). The pens on which the oyster lines are suspended are organised into blocks (Stn P) divided by wide (Stns ZA and ZB) and narrow corridors (Stn SC). A first intense sampling period was conducted in 1991/1992 in order to determine day-to-day variability in 4 different seasons (July 1991, October 1991, January 1992, April 1992). A second longer term study over a 15 mo period in 1993/ 1994 looked at spatial variability. The influence of the shellfish farming zones was studied through the weekly comparison of Stn ZA with Stn RQ, and Stn ZB with Stn TB, from January 1993 to March 1994 (Fig. 1). Surface water $(1 \mathrm{~m})$ was collected in a Niskin bottle aboard the research vessel 'Ostrea III' (IFREMER, Sète) between 10:00 and 11:00 $h$; each Monday for Stns ZA and RQ and biweekly for Stns TB and ZB. Studied parameters were: temperature, salinity, ammonium $\left(\mathrm{NH}_{4}{ }^{+}\right)$, nitrate + nitrite $\left(\mathrm{NO}_{3}{ }^{-}\right)$, phosphate or soluble reactive phosphorus (SRP), dissolved oxygen $\left(\mathrm{O}_{2}\right)$, silicate $(\mathrm{Si})$ and particulate organic carbon and nitrogen (POC and PON). Salinity and temperature were not available for Stns ZB and TB. Salinity data collected in October at Stns RQ and ZA have been published previously in order to show an exceptional influx of Mediterranean waters influenced by the Rhône River plume (Souchu et al. 1997).

In order to assess the influence of the pens, the sampling stations were chosen in Zone B (ZB) for their intermediate depth $(5 \mathrm{~m})$ and their central position (Fig. 1). Stns P, SC, ZB and TB were visited on 4 occasions (July 1991, October 1991, January 1992 and April 1992) during 5 consecutive days at 5 depths $(0.1,1,2,3$ and $4 \mathrm{~m})$. The parameters studied were temperature, salinity, $\mathrm{NH}_{4}{ }^{+}, \mathrm{NO}_{3}{ }^{-}, \mathrm{SRP}$, chl $a$ and pelagic Primary Production (PP). Stn ZB was not sampled in July and not studied for chl a. During the January sequence, a snowstorm prevented us from sampling all variables on the third day (22 January), except for chl a.

Salinity and temperature were recorded with a WTW LF 196 conductimeter (accuracy $\pm 0.5 \%$ ). For $\mathrm{O}_{2}$ measurements, samples were carefully withdrawn from the Niskin bottle, fixed on board and measured by Winkler titration (Aminot 1983). Samples for $\mathrm{NH}_{4}{ }^{+}$determination were fixed on board and mea- 
sured using the method of Koroleff (1976). For other nutrients and particulate matter, the water was prefiltered through a $200 \mu \mathrm{m}$ screen, filtered through a rinsed, precombusted Whatman GF/F filter and stored within $1 \mathrm{~h}$ after sampling. Filtrates were analysed for $\mathrm{NO}_{3}{ }^{-}$and SRP with a segmented flow analyser (Tréguer \& Le Corre 1975). Determinations of POC and PON were performed on filters with a Perkin-Elmer CHN 2400 analyser. Concentrations of chl a were measured by a fluorimetric method (Holm-Hansen et al. 1965) after filtration of $500 \mathrm{ml}$ through a Whatman GF/F filter. Methods are detailed in Souchu et al. (1997).

Primary production ( $\mathrm{PP}, \mu \mathrm{g} \mathrm{C} \mathrm{l}^{-1} \mathrm{~h}^{-1}$ ) was measured according to the method of Steemann-Nielsen (1952). Carbon fixation was measured in $160 \mathrm{ml}$ polycarbonate (PC) light bottles filled with water collected at 0.1, 1, 2, 3 and $4 \mathrm{~m}$ depth. The added bicarbonate activity was from 148 to $370 \mathrm{KBq}$ bottle ${ }^{-1}$ (Amersham specific activity: $1.95 \mathrm{GBq} \mathrm{mmol}^{-1}$ ). In situ incubations lasted $4 \mathrm{~h}$ on average around the middle of the day. At the end of incubations, formalin was added in the bottles $(1 \%$ final concentration) according to Riemann \& Jensen (1991). Then, $40 \mathrm{ml}$ was withdrawn from each bottle and gently filtered through a $25 \mathrm{~mm}$ Millipore HAWP cellulose nitrate membrane. Filters were air dried and acidified with $100 \mu \mathrm{l} 1 \mathrm{~N} \mathrm{HCl}$, placed in $4 \mathrm{ml}$ of scintillation cocktail (Packard Instagel) and assayed with a Packard Tricarb 300 liquid scintillation counter.

The IFREMER observation network provided records of temperature and salinity from 1971 to 1990. Rainfall on the watershed was obtained from the National Meteorological Board of Montpellier, and wind velocities from the automatic records of a meteorological station installed on a pen near Stn ZB (CIMEL Electronique, Paris).

\section{RESULTS}

Results from the spatial survey are presented first, in order to describe the ecological context of the survey and the influence of the shellfish farming. The intensive temporal variability study is presented second, allowing a more detailed description of the phenomena involved in the resulting biogeochemical compositon of the water column.

\section{Weekly variations (1993/1994 survey)}

Water temperature from ZA $(1 \mathrm{~m})$ showed a wide seasonal range from $6^{\circ} \mathrm{C}$ in February to $26^{\circ} \mathrm{C}$ in August (Fig. 2). The total annual rainfall recorded on the watershed $(682 \mathrm{~mm})$ was close to the mean for the past 3 decades $(623 \mathrm{~mm})$. The rainy periods (spring and
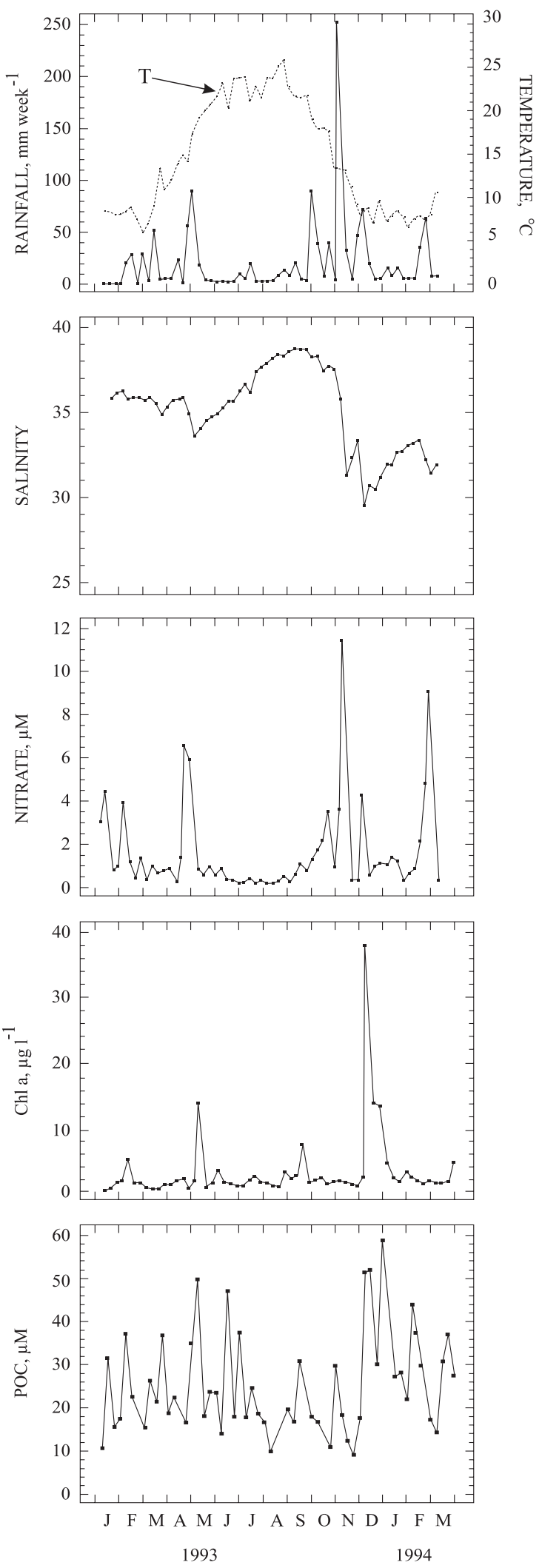

Fig. 2. Time course of rainfall on the watershed and temperature $(\mathrm{T})$, salinity, $\mathrm{NO}_{3}{ }^{-}$, chl a and POC concentrations at Stn ZA from January 1993 to March 1994 

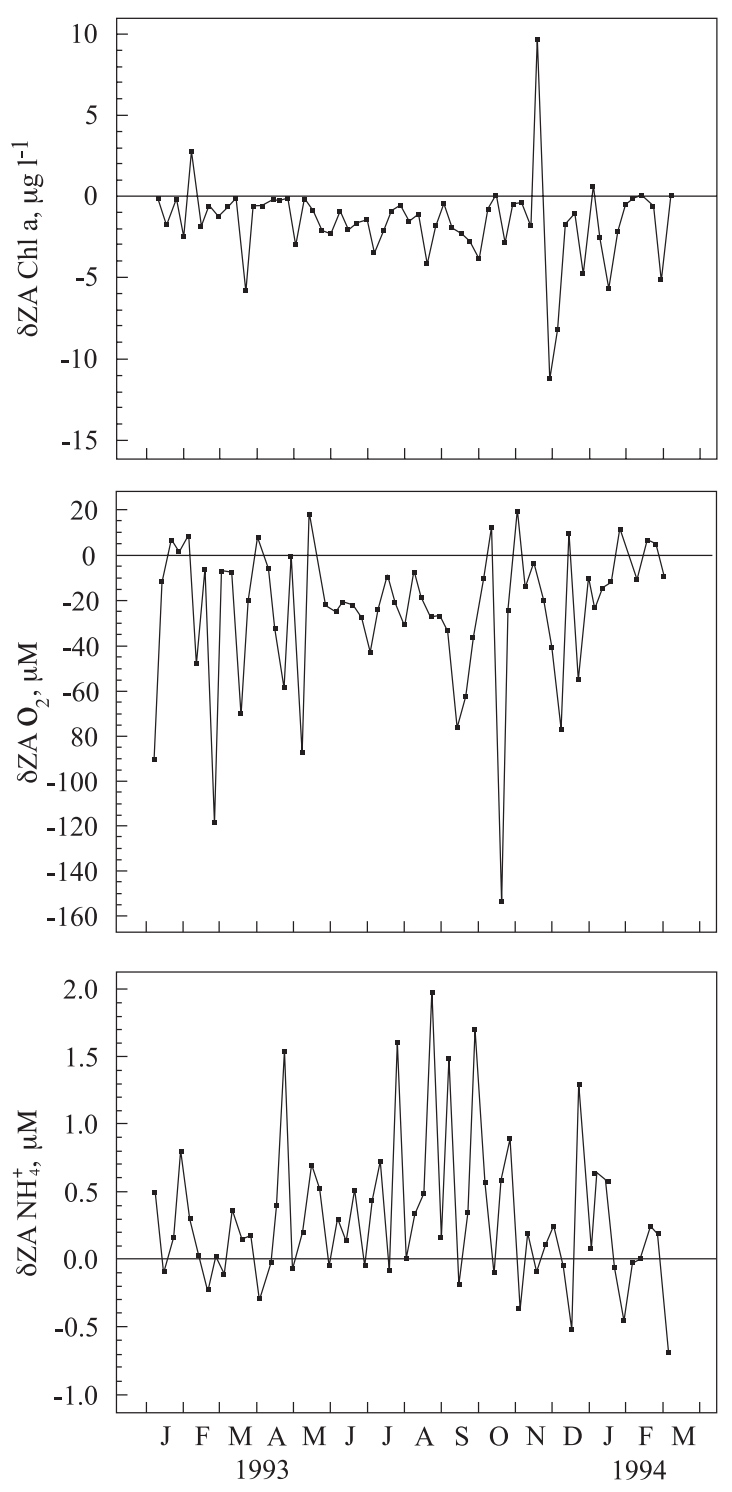

Fig. 3. Time course of the subtraction between paired data, $\mathrm{ZA}-\mathrm{RQ}(\delta \mathrm{ZA})$ for chl $a_{1} \mathrm{O}_{2}$ and $\mathrm{NH}_{4}{ }^{+}$concentrations from January 1993 to March 1994

autumn) corresponded to peak rainfall values, especially in November, which corresponded to more than $40 \%$ of the total annual rainfall (Fig. 2). In April and November, salinity reductions followed, with a lag of $1 \mathrm{wk}$, the occurrence of heavy rainfall on the watershed. The strong salinity reductions corresponded to high $\mathrm{NO}_{3}^{-}$concentrations, which were followed by high chl a concentrations at ZA (Fig. 2). Peak values of POC did not correspond to reductions of salinity. Some of them coincided with high chl a concentrations. Nevertheless, no significant correlation was found between POC and chl $a_{\text {, }}$ and numerous peaks of POC concentrations were measured despite chl a con- centrations below $1 \mu \mathrm{g} \mathrm{l}^{-1}$. Concentrations of POC and PON were strongly correlated: $[\mathrm{POC}]=6.8+$ $5.6[\mathrm{PON}], \mathrm{p}<10^{-5}, \mathrm{r}^{2}=0.68$. Stns RQ, TB and ZB displayed a similar succession of $\mathrm{NO}_{3}{ }^{-}$and chl a peaks following freshwater inputs (not shown).

In order to investigate the influence of shellfish farming, the sampling strategy we used considered Stn ZA and $S$ tn $R Q$ samples as paired data, comparing for each parameter the mean of ZA minus RQ $(\mathrm{ZA}-\mathrm{RQ}=$ $\delta Z A)$ to 0 with $\alpha$ at 0.05 . This 1 -sample analysis was also applied to the second set of data collected in the western part of the lagoon $(\mathrm{ZB}-\mathrm{TB}=\delta \mathrm{ZB})$. Variations of salinity between Stn ZA and Stn RQ were not significant (Table 1), while for temperature, they were significant, with values slightly higher at ZA. The deficit of particulate matter was highly significant in shellfish farming zones, and at both sites a decrease of about 25 and $40 \%$ for POC and chl a concentrations occurred respectively. In November the phytoplankton bloom at ZA was several days ahead of that at $R Q$, which induced a strong variation of $\delta \mathrm{ZA}$ in chl a concentrations (Fig. 3). Concentrations of $\mathrm{O}_{2}$ were significantly lower at stations from the shellfish farming zones, with a mean deficit of under $5 \%$ (Table 1). No seasonal variation of $\delta \mathrm{ZA} \mathrm{O}_{2}$ was observed (Fig. 3), and the strong negative value recorded in October $(<-150 \mu \mathrm{M})$ was clearly related to the entrance of Mediterranean waters, as reported in Souchu et al. (1997). Nutrient concentrations were higher in shellfish farming zones than outside, except for $\mathrm{NO}_{3}{ }^{-}$. The excess of $\mathrm{NH}_{4}{ }^{+}, \mathrm{SRP}$ and $\mathrm{Si}$ concentrations at shellfish farming stations was more significant in the eastern part (due partly to the higher number of samples) and was twice as much as in the western part (Table 1). For $\mathrm{NH}_{4}{ }^{+}, \delta \mathrm{ZA}$ increased in summer (Fig. 3), and significant linear correlations $(p<0.003)$ were found between temperature and $\delta \mathrm{ZA}$ for $\mathrm{NH}_{4}{ }^{+}$, but also for SRP and Si concentrations. Positive but less significant correlations $(\mathrm{p}<0.02)$ were also found between temperature and $\delta \mathrm{ZB}$ for $\mathrm{NH}_{4}{ }^{+}, \mathrm{SRP}$ and $\mathrm{Si}$ concentrations (assuming similar surface temperature for Stns ZA and TB).

\section{Daily variations (1991/1992 survey)}

The 4 study periods were characterised by low precipitation rates compared to those reported over the past 3 decades. Salinity was therefore above the mean values in all seasons (Table 2). Within each season, no variation with time and between stations was found for salinity and temperature (ANOVA, $\mathrm{p}>0.1$ ). Data for $\mathrm{PP}$, nutrients and chl a concentrations did not follow a normal distribution pattern, and a Kruskal-Wallis analysis was applied with stations, days and depth as classification factors (Table 3). For all parameters and 
Table 1 . Results of the $t$-test for the paired observations $\delta \mathrm{ZA}$ and $\delta \mathrm{ZB}(\delta \mathrm{ZA}=\mathrm{ZA}-\mathrm{RQ}, \delta \mathrm{ZB}=\mathrm{ZB}-\mathrm{TB})$. Values are mean values \pm standard error. Values of $\mathrm{p}<0.05$ indicate a significant difference between the oyster sites $(\mathrm{ZA}, \mathrm{ZB})$ and their respective reference sites (RQ, TB). (ND, not determined; NS, not significant)

\begin{tabular}{|c|c|c|c|c|c|c|c|c|}
\hline & \multicolumn{2}{|c|}{$\begin{array}{l}\text { Variation between } \\
\text { shellfish-farming and } \\
\text { reference sites }\end{array}$} & \multicolumn{2}{|c|}{$\begin{array}{l}\text { Sig. level of } t \text {-test (p) } \\
\text { at } \alpha=0.05\end{array}$} & \multicolumn{2}{|c|}{$\begin{array}{c}\text { Mean at reference } \\
\text { sites }\end{array}$} & \multicolumn{2}{|c|}{$\begin{array}{l}\text { Deficit or excess } \\
\text { compared to } \\
\text { reference sites (\%) }\end{array}$} \\
\hline & $\begin{array}{c}\delta \mathrm{ZA} \\
\mathrm{n}=60\end{array}$ & $\begin{array}{c}\delta \mathrm{ZB} \\
\mathrm{n}=30\end{array}$ & $\begin{array}{c}\delta \mathrm{ZA} \\
\mathrm{n}=60\end{array}$ & $\begin{array}{c}\delta \mathrm{ZB} \\
\mathrm{n}=30\end{array}$ & $\begin{array}{c}\mathrm{RQ} \\
\mathrm{n}=60\end{array}$ & $\begin{array}{l}\text { TB } \\
\mathrm{n}=30\end{array}$ & $\begin{array}{c}\delta \mathrm{ZA} / \mathrm{RQ} \\
\mathrm{n}=60\end{array}$ & $\begin{array}{r}\delta \mathrm{ZB} / \mathrm{TB} \\
\mathrm{n}=30\end{array}$ \\
\hline $\mathrm{T},{ }^{\circ} \mathrm{C}$ & $0.12 \pm 0.05$ & ND & 0.02 & ND & $14.3 \pm 0.8$ & ND & $0.6 \pm 0.4$ & ND \\
\hline Salinity & $0.03 \pm 0.05$ & ND & 0.60 & ND & $34.9 \pm 0.3$ & ND & NS & ND \\
\hline Chl $a, \mu g \mathrm{l}^{-1}$ & $-1.7 \pm 0.3$ & $-1.2 \pm 0.5$ & $<10^{-5}$ & 0.03 & $4.2 \pm 0.7$ & $3.2 \pm 0.3$ & $-44 \pm 4$ & $-41 \pm 5$ \\
\hline POC, $\mu \mathrm{M}$ & $-12.6 \pm 2.4$ & $-8.3 \pm 2.1$ & $<10^{-5}$ & $<10^{-3}$ & $39.4 \pm 2.6$ & $29.1 \pm 2.6$ & $-26 \pm 9$ & $-21 \pm 5$ \\
\hline $\mathrm{O}_{2}, \mu \mathrm{M}$ & $-25 \pm 4$ & $-18.7 \pm 8.0$ & $<10^{-6}$ & 0.03 & $530 \pm 11$ & $480 \pm 34$ & $-4.7 \pm 0.8$ & $-3.6 \pm 1.8$ \\
\hline $\mathrm{NH}_{4}^{+}, \mu \mathrm{M}$ & $0.31 \pm 0.07$ & $0.17 \pm 0.10$ & $<10^{-4}$ & 0.04 & $1.02 \pm 0.15$ & $1.00 \pm 0.15$ & $73 \pm 16$ & $36 \pm 17$ \\
\hline $\mathrm{SRP}, \mu \mathrm{M}$ & $0.10 \pm 0.02$ & $0.09 \pm 0.04$ & $<10^{-3}$ & 0.04 & $0.47 \pm 0.05$ & $0.57 \pm 0.48$ & $36 \pm 12$ & $14 \pm 7$ \\
\hline $\mathrm{Si}, \mu \mathrm{M}$ & $0.78 \pm 0.35$ & $1.7 \pm 0.2$ & 0.03 & 0.009 & $9.2 \pm 0.8$ & $11.0 \pm 1.1$ & $19 \pm 8$ & $13 \pm 6$ \\
\hline $\mathrm{NO}_{3}^{-}, \mu \mathrm{M}$ & $0.21 \pm 0.21$ & $0.02 \pm 0.19$ & 0.32 & 0.89 & $1.2 \pm 0.2$ & $0.8 \pm 0.2$ & NS & NS \\
\hline
\end{tabular}

Table 2. Precipitation on the watershed, daily-averaged wind speed, temperature and salinity in Thau lagoon during the study periods compared to past decades. Salinity and temperature are averages at stations for each $5 \mathrm{~d}$ sequence. Values are mean values \pm standard error

\begin{tabular}{|lcrrr|}
\hline & Jul 1991 & Oct 1991 & Jan 1992 & Apr 1992 \\
\hline Rainfall $\left(\mathrm{mm} \mathrm{mo}^{-1}\right.$ ) & 10 & 64 & 45 & 16 \\
Mean rainfall from 1961 to 1995 & 13 & 110 & 61 & 46 \\
Windspeed $\left(\mathrm{m} \mathrm{s}^{-1}\right.$ ) & $5.2 \pm 1.2$ & $3.4 \pm 0.6$ & $6.1 \pm 2.5$ & $4.7 \pm 1.1$ \\
Salinity & $37.1 \pm 0.1$ & $39.1 \pm 0.1$ & $37.9 \pm 0.2$ & $37.4 \pm 0.0$ \\
Monthly salinity from 1971 to 1990 & $36.5 \pm 1.6$ & $37.8 \pm 1.2$ & $35.9 \pm 2.3$ & $34.6 \pm 1.7$ \\
Temperature $\left({ }^{\circ} \mathrm{C}\right)$ & $24.8 \pm 0.3$ & $17.3 \pm 0.3$ & $5.1 \pm 0.5$ & $11.9 \pm 0.2$ \\
Mean temperature from 1971 to 1990 & $23.4 \pm 1.9$ & $12.6 \pm 1.7$ & $6.6 \pm 1.8$ & $12.6 \pm 1.7$ \\
\hline
\end{tabular}

Table 3. Kruskal-Wallis analysis comparing stations ( $\mathrm{P}, \mathrm{SC}, \mathrm{ZB}$ and TB), time (day) and depth layers (0.1 to $4 \mathrm{~m})$ for primary production ( $\left.\mathrm{PP}, \mu \mathrm{g} \mathrm{C} \mathrm{l}^{-1} \mathrm{~h}^{-1}\right)$, chlorophyll a concentration (chl $\left.a, \mu \mathrm{g} \mathrm{chl} \mathrm{l} \mathrm{l}^{-1}\right)$ and nutrient concentrations $(\mu \mathrm{M})(+++, \mathrm{p}<0.001 ;++, \mathrm{p}<$ $0.01 ;+, \mathrm{p}<0.05 ; \mathrm{NS}$, not significant). Values are mean values \pm standard error (SRP, soluble reactive phosphorus)

\begin{tabular}{|c|c|c|c|c|c|c|}
\hline \multirow[t]{2}{*}{ Time } & \multirow{2}{*}{ Parameter } & \multirow{2}{*}{$\begin{array}{l}\text { Samples } \\
\text { (n) }\end{array}$} & \multirow{2}{*}{$\begin{array}{l}\text { Mean } \\
( \pm \text { SE })\end{array}$} & \multicolumn{3}{|c|}{ Probability } \\
\hline & & & & Station & Day & Depth \\
\hline \multirow{5}{*}{$\begin{array}{l}15-19 \text { Jul 1991, } \\
25^{\circ} \mathrm{C}\end{array}$} & PP & 40 & $19.1 \pm 1.3$ & +++ & +++ & NS \\
\hline & Chl a & 40 & $2.01 \pm 0.10$ & +++ & +++ & NS \\
\hline & $\mathrm{NH}_{4}^{+}$ & 75 & $0.49 \pm 0.06$ & NS & +++ & NS \\
\hline & $\mathrm{NO}_{3}^{-}$ & 75 & $0.79 \pm 0.08$ & NS & +++ & NS \\
\hline & SRP & 75 & $0.92 \pm 0.02$ & ++ & +++ & NS \\
\hline \multirow{5}{*}{$\begin{array}{l}14-18 \text { Oct } 1991, \\
17^{\circ} \mathrm{C}\end{array}$} & $\mathrm{PP}$ & 75 & $5.94 \pm 0.41$ & +++ & ++ & +++ \\
\hline & Chl $a$ & 75 & $1.14 \pm 1.17$ & +++ & ++ & NS \\
\hline & $\mathrm{NH}_{4}{ }^{+}$ & 100 & $1.89 \pm 0.09$ & +++ & +++ & NS \\
\hline & $\mathrm{NO}_{3}^{-}$ & 100 & $1.07 \pm 0.06$ & +++ & +++ & NS \\
\hline & SRP & 100 & $0.74 \pm 0.02$ & NS & +++ & NS \\
\hline \multirow{5}{*}{$\begin{array}{l}20-24 \text { Jan 1992, } \\
5^{\circ} \mathrm{C}\end{array}$} & $\mathrm{PP}$ & 60 & $1.31 \pm 0.10$ & NS & +++ & +++ \\
\hline & Chl a & 60 & $1.41 \pm 1.03$ & +++ & +++ & NS \\
\hline & $\mathrm{NH}_{4}{ }^{+}$ & 80 & $0.62 \pm 0.12$ & +++ & +++ & NS \\
\hline & $\mathrm{NO}_{3}^{-}$ & 80 & $0.65 \pm 0.02$ & NS & + & NS \\
\hline & SRP & 80 & $0.28 \pm 0.03$ & ++ & +++ & NS \\
\hline \multirow{5}{*}{$\begin{array}{l}6-10 \text { Apr 1992, } \\
12^{\circ} \mathrm{C}\end{array}$} & $\mathrm{PP}$ & 75 & $3.27 \pm 0.08$ & +++ & NS & NS \\
\hline & Chl a & 75 & $0.91 \pm 0.02$ & +++ & ++ & NS \\
\hline & $\mathrm{NH}_{4}^{+}$ & 100 & $0.51 \pm 0.14$ & +++ & +++ & NS \\
\hline & $\mathrm{NO}_{3}^{-}$ & 100 & $1.01 \pm 0.01$ & NS & +++ & NS \\
\hline & $\mathrm{SRP}$ & 100 & $0.19 \pm 0.02$ & NS & +++ & NS \\
\hline
\end{tabular}



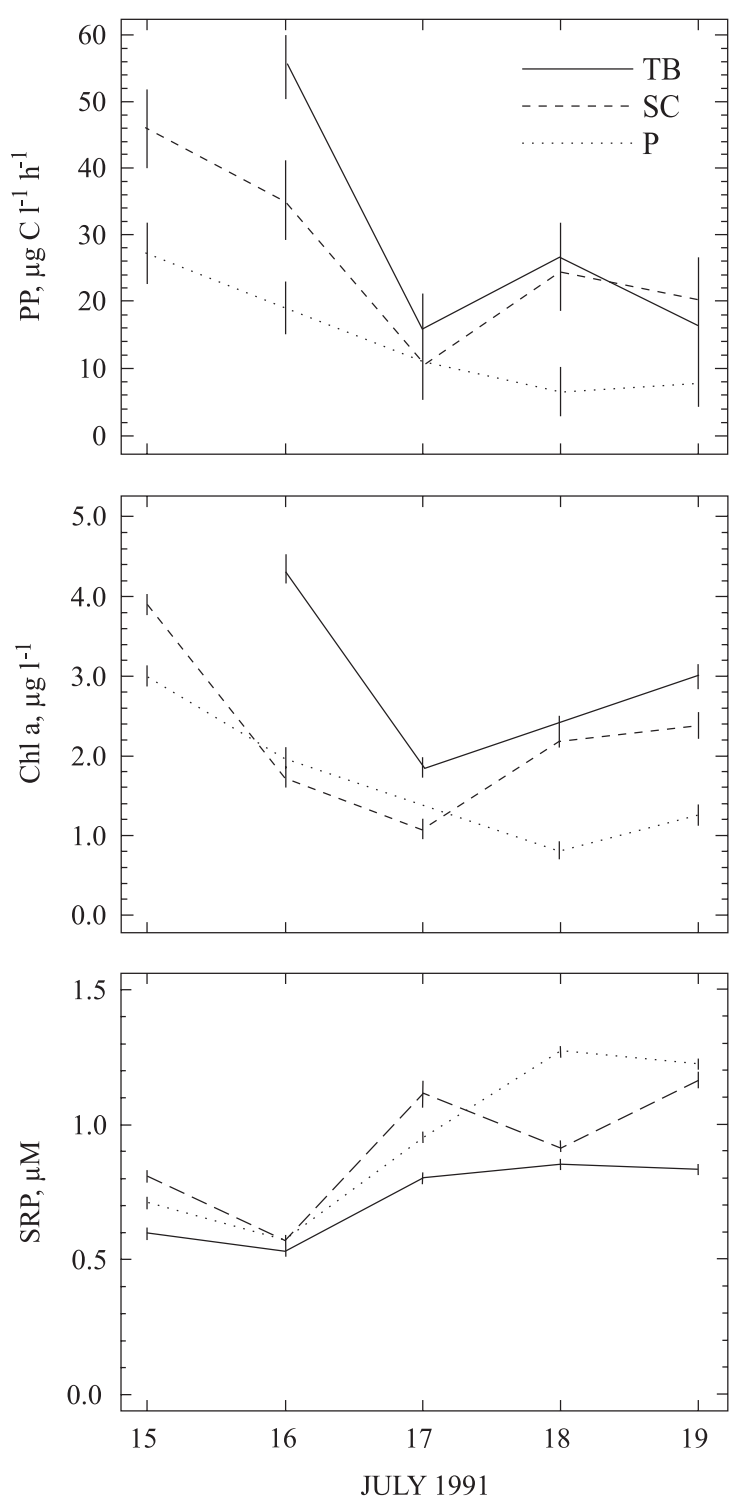

Fig. 4. Daily variations in primary production (PP), chlorophyll a $(\mathrm{chl} \mathrm{a})$ and soluble reactive phosphorus (SRP) concentrations in July 1991. Oyster pens (P), narrow corridor (SC) and outside the shellfish farming zone (TB). Values are mean values \pm standard error

all seasons, daily variations were always significant except for PP in April, while no significant variation with depth was found, except for PP in October and January. The influence of stations was variable depending on the parameter and the study period.

In July, winds were moderate, from a westerly direction (Table 2). This season was a period of maximum PP (Table 3), which varied from $13.3 \pm 1.2 \mu \mathrm{g} \mathrm{C} \mathrm{l}^{-1} \mathrm{~h}^{-1}$ in the pens ( $\operatorname{Stn} \mathrm{P}$ ) to $27.4 \pm 3.9 \mu \mathrm{g} \mathrm{C} \mathrm{l}^{-1} \mathrm{~h}^{-1}$ outside the shellfish farming zone (Stn TB). Daily variations of PP were strong at the 3 stations but relatively low at Stn P
(Fig. 4). Concentrations of chl a were maximum in July (Table 3). They were always lower in the shellfish farming zone than outside but remained above $1 \mu \mathrm{g} \mathrm{l}^{-1}$ at Stn P (Fig. 4). In July, concentrations of $\mathrm{NH}_{4}{ }^{+}$were the lowest reported in this study with no significant variation between stations (Table 3). In contrast, SRP concentrations reached their maximum in July, displaying higher levels in the shellfish farming zone than outside (Fig. 4).

In October the lowest wind speed was recorded, with a mean value under $4 \mathrm{~m} \mathrm{~s}^{-1}$; temperature was well above the mean (Table 2). Mean PP was 2/3 lower than in July (Table 3), and decreased from $12.6 \pm 0.9 \mu \mathrm{g} \mathrm{Cl}^{-1}$

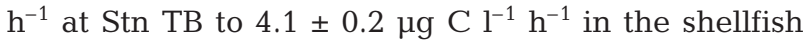
farming zone (Fig. 5). Concentrations of chl a displayed a similar pattern (Fig. 5), with a noticeable attenuation of daily variations in the shellfish farming zone. Concentrations of $\mathrm{NH}_{4}{ }^{+}$were the highest recorded during the daily study (Table 3), and were significantly higher in pens (Stn P) than outside (Stn ZB, $\mathrm{SC}$ and $\mathrm{TB}$ ) during almost the entire $5 \mathrm{~d}$ sequence (Fig. 5). At Stn TB, the strong increase of chl a concentrations from 15 to 16 October corresponded to the depletion of $\mathrm{NH}_{4}{ }^{+}$concentrations. In the shellfish farming zone, the decrease of $\mathrm{NH}_{4}{ }^{+}$concentrations was more closely related to the increase of $\mathrm{NO}_{3}{ }^{-}$concentrations. Significantly higher levels of $\mathrm{NO}_{3}^{-}$concentrations in the shellfish farming zone were also recorded during this season (Table 3).

January was characterised by a storm coming from a north-easterly direction, with wind speeds rising above $10 \mathrm{~m} \mathrm{~s}^{-1}$. During this cold period, PP was close to the detection limits, and did not show significant difference between the shellfish farming zone and outside (Fig. 6). Before the storm, chl a concentrations were close to $1 \mu \mathrm{g} \mathrm{l}^{-1}$ at Stn TB but near $0.8 \mu \mathrm{g} \mathrm{l}^{-1}$ in the shellfish farming zone. They increased drastically after the storm, with chl a reaching $7 \mu \mathrm{g}^{-1}$ at TB (Fig. 6) and dropping to near $1 \mu \mathrm{g} \mathrm{l^{-1 }}$ the day after. This peak value of chl a concentrations was not observed for PP. Despite the strong mixing induced by winds, the influence of the shellfish farming zone on nutrients was significant, except for $\mathrm{NO}_{3}^{-}$(Table 3).

In April, the wind was moderate (Table 2), blowing from a north-westerly direction. During this entire sequence, PP was under $5 \mu \mathrm{g} \mathrm{C}^{-1} \mathrm{~h}^{-1}$, but significantly lower in the shellfish farming zone (Stn SC, P) than at Stn TB (Table 3, Fig. 7). Concentrations of chl a were also lower in the shellfish farming zone with levels similar to those reported at the same stations in October and January before the storm (Fig. 7). Concentrations of $\mathrm{NH}_{4}{ }^{+}$were below $1 \mu \mathrm{M}$, but significantly higher in the shellfish farming zone than outside (Fig. 7). Nevertheless, no differences between pens and corridors were observed. 

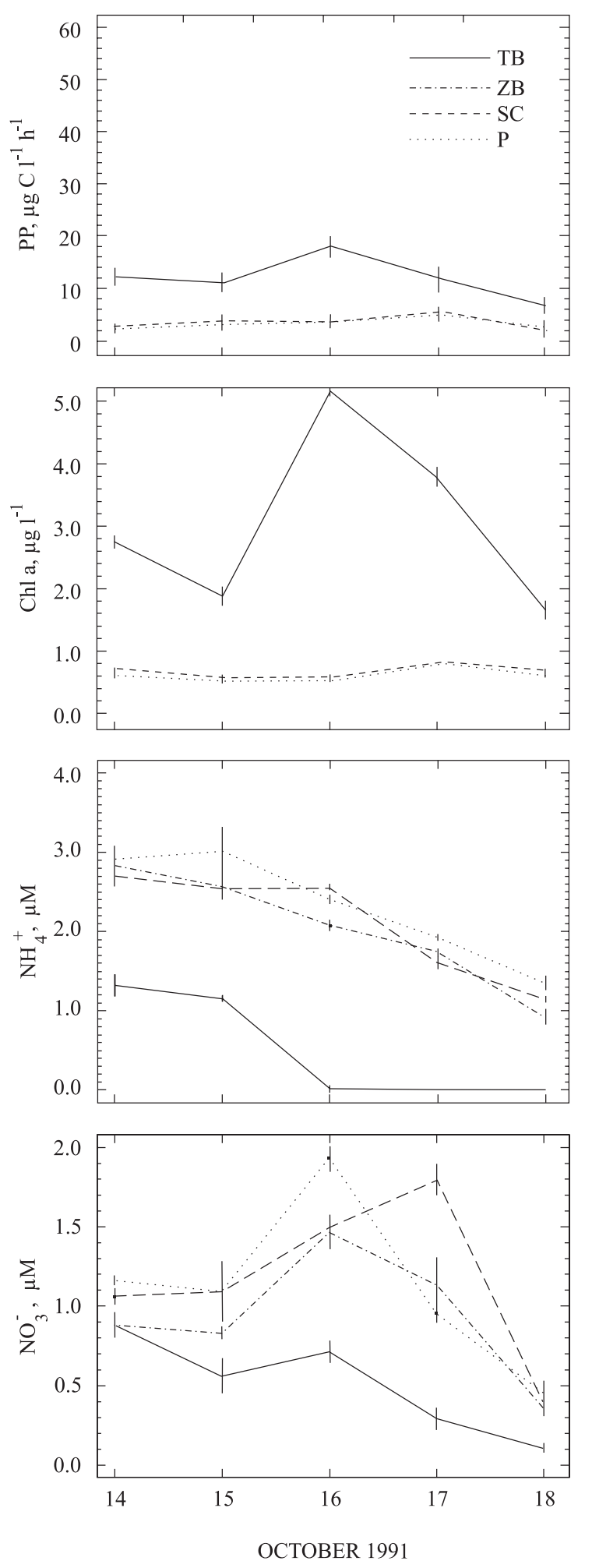

Fig. 5. Daily variations in $\mathrm{PP}, \mathrm{chl} a, \mathrm{NH}_{4}{ }^{+}$and $\mathrm{NO}_{3}{ }^{-}$concentrations in October 1991. Oyster pens (P), wide corridor (ZB), narrow corridor (SC) and outside the shellfish farming zone

(TB). Values are mean values \pm standard error
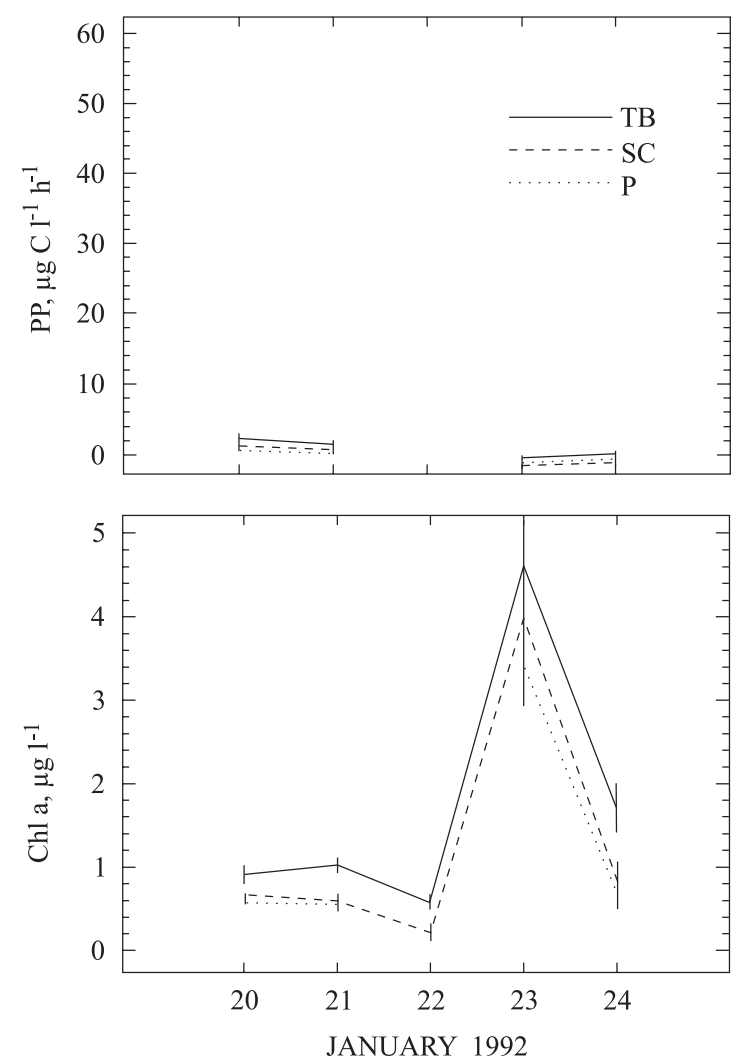

Fig. 6. Daily variations in PP and chl a concentrations in January 1992. Oyster pens (P), narrow corridor (SC) and outside the shellfish farming zone (TB). Values are mean values \pm standard error

\section{DISCUSSION}

In contrast to the shellfish farming areas of the Atlantic coast, where nutrient cycling is more likely to be controlled by physical phenomena such as tides and sediment resuspension, the intensive shellfish farming of the Thau lagoon will impact the water column more through biological phenomena, except during the rare wind events (see below).

Due to the Mediterranean climate, this ecosystem receives erratic but strong discharges of freshwater from its watershed, which intermittently provide nutrients to the water column. Primary production transforms these nutrients into particulate matter. The grazing of heterotrophic communities on phytoplankton (Lam Hoai et al. 1997) should explain several peak values of POC concentrations, and particularly those following peaks in chl a concentrations. The relationship between PON and POC concentrations at ZA is similar to that reported from data collected in summer 1994 at the same station (Souchu et al. 1998). The slope is close to the Redfield C:N ratios in plankton, and the intercept, interpreted as the non-degradable fraction 

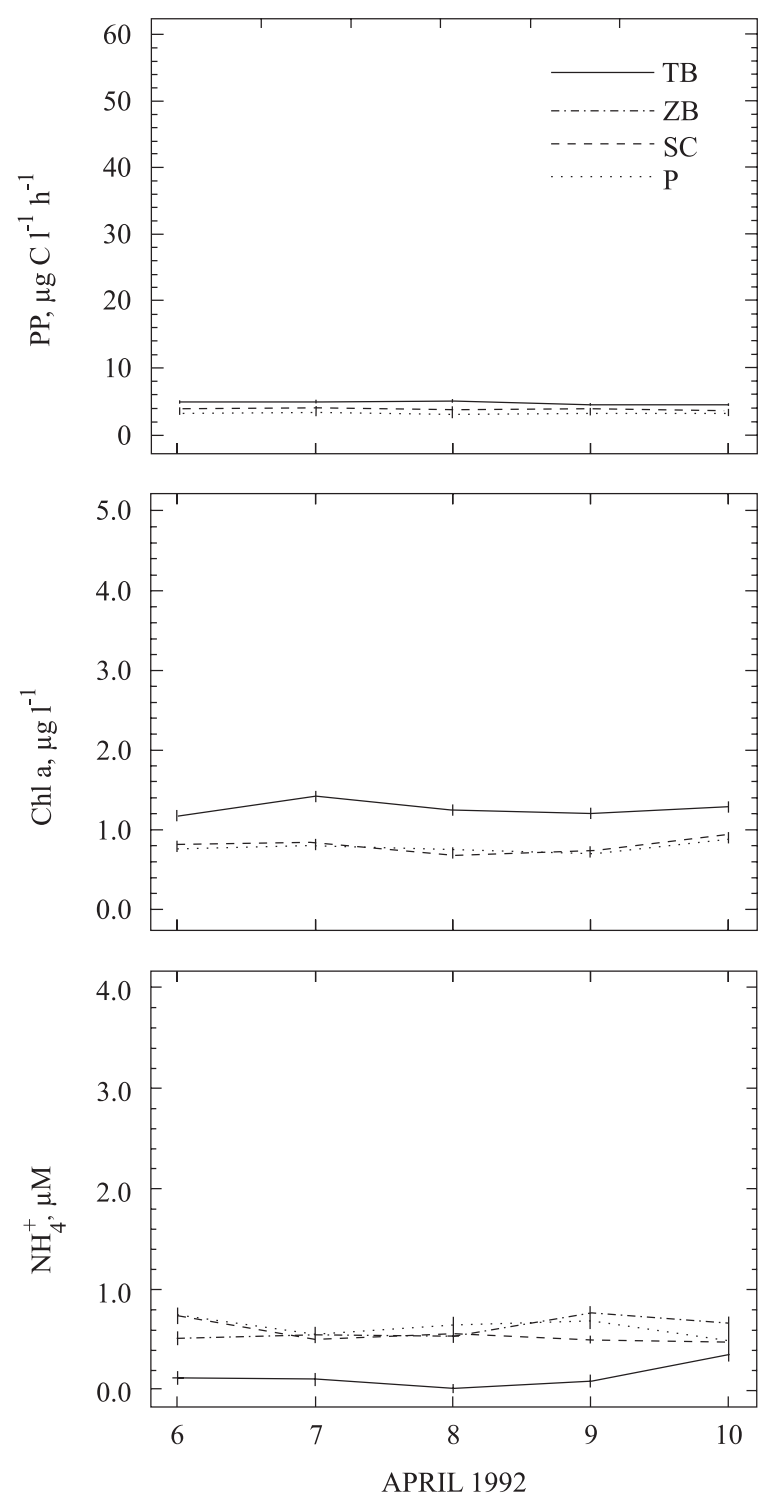

Fig. 7. Daily variations in $\mathrm{PP}, \mathrm{chl}$ a and $\mathrm{NH}_{4}{ }^{+}$concentrations in April 1992. Oyster pens (P), wide corridor (ZB), narrow corridor (SC) and outside the shellfish farming zone (TB). Values are mean values \pm standard error

(Copin-Montégut \& Copin-Montégut 1983), does not exceed $20 \%$ of the mean POC concentration.

Increasing chl a concentrations reported in January (Fig. 6) could not come from enhanced pelagic primary production because new inputs of nutrients were unlikely in view of the rainfall and salinity (Table 2). These high chl a concentrations, coupled with low PP, were undoubtedly due to resuspended microphytobenthos, which are abundant in Thau lagoon; biomasses range from 50 to $250 \mathrm{mg} \mathrm{chl} \mathrm{a} \mathrm{m}^{-2}$ at $\mathrm{ZB}$ (Barranguet et al. 1994, Denis et al. 1996). Benthic resuspension can occur when winds blow strongly lengthwise to the lagoon (Cugier et al. unpubl. data). The wind distribution pattern (Fig. 1) shows a strong dominance of winds blowing from a north-westerly direction, or across the width of the lagoon. Winds blowing lengthwise along the lagoon (north-east and south-west) are less frequent $(<10 \%)$, and wind speeds above $10 \mathrm{~m} \mathrm{~s}^{-1}$ are also rare $(<10 \%)$. Therefore, due to the low tide range $(<1 \mathrm{~m}$, Millet 1989) and the rare occurrence of strong winds blowing from northeasterly and south-westerly directions (Fig. 1), benthic resuspension must be considered an exceptional event in this ecosystem. Consequently, only the first $2 \mathrm{~d}$ of the January sequence (before the storm) should be considered the typical winter situation, with minimum levels of PP and chl a concentration. In Thau lagoon, filter feeders thus subsist essentially on the plankton production.

Despite strong seasonal variations in Thau lagoon during the weekly study, Stns ZA and RQ showed similar salinity patterns without significant difference. The very small but significantly higher temperature at ZA (Table 1) could be due to the decrease of advective processes induced by pens (Grenz et al. unpubl. data). The non-significance of $\delta \mathrm{ZA}$ for $\mathrm{NO}_{3}{ }^{-}$(Table 1 ) showed that both stations received similar freshwater inputs from the watershed. The same can be said for chl $a$, except for 2 samples. The exchange between Mediterranean waters and the lagoon can also induce variations between $\mathrm{ZA}$ and $\mathrm{RQ}$, but the influence of Mediterranean waters was clearly detected only in October during the study period (Souchu et al. 1997). We could then state that Stns ZA and RQ were located in the same water mass and that the differences in biogeochemical parameters were due essentially to shellfish farming activities. Although no salinity and temperature data were available at Stns ZB and TB during the weekly study, results from the daily study enabled us to assume that Stns TB, ZB, SC and P belong to the same water mass (Table 2). The deficit of chl a concentrations $(>40 \%$ ) in shellfish farming zones (Table 1) is higher than the 13 to $25 \%$ calculated in $1986 / 1987$ by Jarry et al. (1990), even if the distinct sampling strategies preclude a strict comparison between the 2 studies. Lam Hoai et al. (1997) measured, in shellfish farms, a deficit in microzooplankton biomasses (40 to $200 \mu \mathrm{m}$ pore size) corresponding to about $30 \%$. The difference in deficit between chl $a$ and POC is probably due to the preferential grazing of filter feeders on phytoplankton.

During the daily study, no heavy rainfall and, consequently, no significant decrease of salinity was recorded (Table 2). Very little input of nutrient-enriched freshwater was thus expected, and PP measurements accordingly corresponded essentially to regenerated production. Except for July, chl a concentrations remained near or below $0.9 \mu \mathrm{g} \mathrm{l}^{-1}$ at stations inside the 
shellfish farming zone. These low chl a levels are very close to the concentration of $0.51 \mu \mathrm{g} \mathrm{l^{-1 }}$ reported for the mean annual picophytoplankton biomass in Thau lagoon (Courties et al. 1994). Moreover, insignificant/low daily variations at these stations indicate that phytoplankton was filtered as soon as it was produced through PP. It may be assumed that, except for the summer period, regenerated production limits the filter feeders' production. During seasons other than summer, the daily study tends also to show a strong homogeneity in chl a and PP of stations located in the shellfish farming zone. Corridors strongly undergo the pressure of filtration and should be considered cultivated areas. They act as fallow areas that contribute to maintaining phytoplankton production near pens. Bacher et al. (1997) developed a model on the impact of filter feeders by coupling a 2D transport equation and a simple model of the nitrogen cycle. The model explains that the shellfish farming zones on the whole import phytoplankton from the other parts of Thau lagoon through advection. However, our results show that the lagoon is not filtered uniformly by shellfish and their epibiota.

July was the only season when chl a levels were near or above $1 \mathrm{\mu g}^{-1}$ in the shellfish farming zone. Similarly, during July, PP was above $10 \mu \mathrm{g} \mathrm{C}^{-1} \mathrm{~h}^{-1}$ in pens and corridors, with lower but still significant daily variations relative to water outside the shellfish farming zones. This suggests that the grazing pressure did not prevent phytoplankton from accumulating in the shellfish farming waters. Filter feeders display maximum clearance rates during summer (Mazouni et al. 1998b). The warm season should be a key period for their growth, which is assumed not to be limited by food availability. The IFREMER REMORA monitoring network (Le Bec \& Mazurie 1992) found maximum growth rates for Crassostrea gigas during summer in Thau lagoon (Fleury et al. 1999), which confirms this hypothesis. Nevertheless, the deficit of chl $a$ is not limited to pens during July, but the influence of pens compared to corridors shows the strong pressure on phytoplankton by filter feeders which could refilter water in their vicinity (Jordan \& Valiela 1982).

The utilisation of the primary production:biomass ratio $(P: B)$ as an index of phytoplankton specific growth rate is not always justified, because changes in this compound variable could be due to variations in cell pigmentation alone (Falkowski 1981). However, given the quasi-synoptic sampling design used here, it is probably safe to assume that cell pigmentation was constant between stations on a given date. It is therefore justifiable to make between-station comparisons on a given date (Fig. 8).

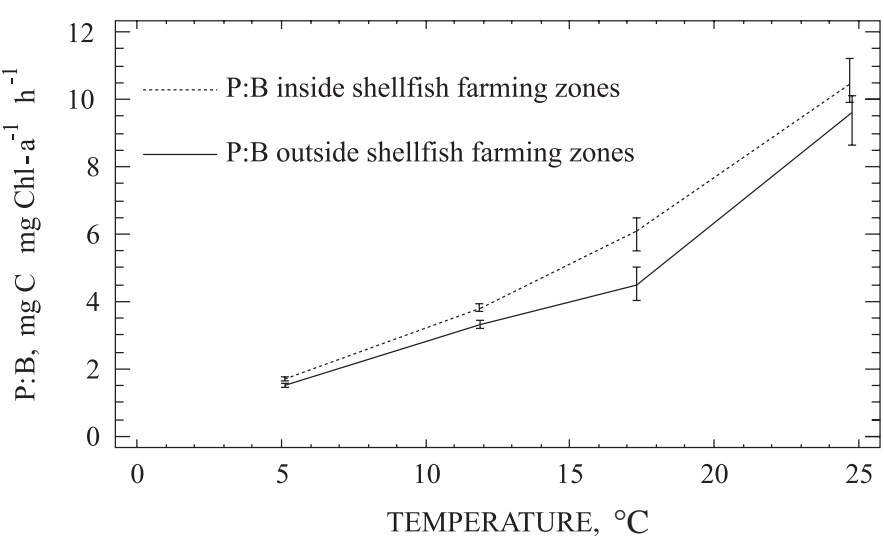

Fig. 8. Plot of $P: B$ ratios versus temperature inside and outside the shellfish farming zones in Thau lagoon. Values are mean values \pm standard error

In Thau lagoon, the regenerated production is notably limited by inorganic nutrients and especially by dissolved inorganic nitrogen (DIN), which is the first factor limiting summer primary production in Thau lagoon (Picot et al. 1990). Consequently, DIN concentrations reach their minimum values in summer under the pressure of primary producers. In contrast, benthic fluxes of SRP are enhanced during summer and tend to accumulate in the water column (Souchu et al. 1998). The regenerated primary production is then controlled by endogenous DIN fluxes at the watersediment interface (Mazouni et al. 1998a) and in the water itself through the microbial loop (Gasc 1997). These $\mathrm{NH}_{4}{ }^{+}$fluxes, which are temperature dependent, should be responsible for the strong increase of primary production during summer. This process explains the significant correlations $(\mathrm{p}<0.05)$ between $P: B$ and temperature inside and outside the shellfish farming zones (Fig. 8).

Picophytoplankton dominates numerically the phytoplankton assemblage in Thau lagoon (ChrétiennotDinet et al. 1995), but nanoplanktonic diatoms mainly contribute to the phytoplanktonic biomass on a yearly basis. However, in summer, picophytoplankton, and notably Ostreococcus tauri, production is largely responsible for the strong increase of $P: B$ ratios (Courties et al. 1994). O. tauri was reported to have a maximum growth rate of 4.2 divisions $\mathrm{d}^{-1}$ in cultures (Courties et al. 1998), which can match those of diatoms (Furnas 1990). The effect of shellfish farming on phytoplanktonic group abundance was studied in parallel to our daily sampling by Vaquer et al. (1996). Even if reared oysters are associated with numerous epifaunal species (Mazouni et al. 1998a), which are filter feeders with higher retention efficiency (David 1971), Vaquer et al. (1996) did not notice any significant influence of shellfish farming zones on the abundance of pico- 
planktonic cells. However, these authors found higher abundance of nanoplanktonic and larger cells at Stn TB than at Stn ZB in July, October and April, but not in January. Filter feeders induce a shift in phytoplankton composition towards small cells with faster growth rates (Prins et al. 1998). Shellfish farming areas tend to increase the $P: B$ ratios in their vicinity (Fig. 8). This shift in growth rate is not significant during summer, because the effect of increasing temperature, which is much more important, tends to override the influence of shellfish farming zones.

The particulate matter filtered by filter feeders can be recycled in underlying sediments after biodeposition (Deslous-Paoli et al. 1992) and directly through excretion (Bayne \& Scullard 1977). The enrichment of surface waters in the vicinity of shellfish farms with $\mathrm{NH}_{4}{ }^{+}$, SRP and Si illustrates this heterotrophic component induced by bivalves in their ecosystem (Prins \& Smaal 1994). The positive linear relationship between temperature and the excess of $\mathrm{NH}_{4}{ }^{+}, \mathrm{SRP}$ and $\mathrm{Si}$ concentrations at shellfish farming stations should be linked to those existing between temperature and nutrient benthic fluxes reported in Thau lagoon by Mazouni et al. (1996). The cyclical pattern of variation between $\mathrm{NH}_{4}{ }^{+}$, SRP and $\mathrm{Si}$ concentrations suggests that biodeposits accumulate at the water-sediment interface and are recycled to a large extent during the warm season due to enhanced remineralisation processes (Sornin et al. 1990). The excretion rates of filter feeders are also temperature dependent and display summer maxima (Kautsky \& Wallentinus 1980, Mazouni et al. 1998b). Moreover, oysters and their epibiota can retain biodeposits and other sinking organic particles which can accumulate at the water-filter feeder interface. The former displays similar components to those encountered at the sediment-water interface such as positive $\mathrm{NO}_{3}{ }^{-}$fluxes (nitrifying bacteria) and polychaetes (Mazouni et al. 1998a,b). Therefore, the respective contribution of water-sediment and water-filter feeder interfaces to the summer increase of nutrient fluxes are difficult to quantify from this study. Nevertheless, biogenic silicon from diatoms may be biodeposited to a much greater extent than excreted by filter feeders (Prins \& Smaal 1994). It is thus likely that biodeposition prevails quantitatively over recycling processes in shellfish farms (Jordan \& Valiela 1982, Kim 1983, Kaspar et al. 1985, Hawkins \& Bayne 1985).

In the surrounding vicinity, the presence of shellfish farms leads to a decrease of $\mathrm{O}_{2}$ concentrations by only a few percent. The respiration by oysters (and associated epifauna) coupled with the decreased production due to the deficit in phytoplankton biomass do not represent an important oxygen sink for the water column (Table 1). In Thau lagoon, the oxygen demand by sedi- ments is the major biological process influencing the oxygen cycle (Mazouni et al. 1996). Souchu et al. (1998) showed that bottom anoxia can develop in the deepest parts of the lagoon in summer, and outside (RQ) as well as inside (ZA) shellfish farming areas. Consequently, biodeposition cannot be considered as responsible for excessive oxygen consumption.

The excess of nutrients from shellfish farms is lower in the western part (ZB) than in the eastern part (Table 1), because, due to shallower depth, sediments in the western areas receive sufficient light to permit the development of algal mats and eelgrass, Zostera marina (Gerbal \& Verlaque 1995). In the eastern part, especially in the deepest shellfish farming area (>6 m), benthic macroflora communities are virtually absent, because light limitation and recurrent summer bottom anoxia prevent them from permanent colonisation. Consequently, their uptake of benthic nutrients is lower than in the western part of the lagoon. Nutrients from benthic fluxes and, among others, nutrients remineralised from biodeposits are more readily available to phytoplankton in the eastern shellfish farming zone than in the western part, where competition from benthic macroalgae is stronger. This difference, induced by the depth, tends to favour filter feeders reared in the deepest part of the lagoon. Oysters from the ZA sector do indeed have better growth rates of about $40 \%$ than those reared in the western part (Fleury et al. 1999, and other REMORA reports)

The decline of phytoplankton biomasses in the vicinity of shellfish farms tends to reduce the pressure on nutrients. This situation is likely to favour benthic flora but also pelagic nitrifying bacteria, although the former can be inhibited by light in summer (Ward 1985, Souchu et al. 1997). Early autumn is often characterised by an increase of $\mathrm{NH}_{4}{ }^{+}$concentration, probably due to the decay of summer communities in the water column (Gilbert et al. 1997). In October (Fig. 5), $\mathrm{NH}_{4}{ }^{+}$ was depleted by primary production at the station outside the shellfish farming zone, while it was probably more nitrified in pens and corridors. Therefore, filter feeders are able, at certain times, to alter the dominant process in the water column by stimulating nitrification. This is an important new feedback process in bivalve-dominated ecosystems which could be added to those reported by Prins et al. (1998).

\section{Conclusions}

Thau lagoon is a shellfish ecosystem with a different pattern of functioning from many of those studied on the Atlantic coast, where strong tides and steady freshwater inputs provide filter feeders with materials other than plankton (Héral et al. 1983, Smaal \& Haas 1997). 
The impact of shellfish farms with suspended ropes has been investigated in ecosystems with low densities of filter feeders (Souchu et al. 1991) or with strong tidal currents (Kaspar et al. 1985), and no significant influence of filter feeders was found. Thau lagoon displays a case of large biomasses of filter feeders growing in waters with high residence time due to low tides. The influence of shellfish farming on the in situ water chemistry is therefore significant during all seasons, and, except for summer, filter feeder growth is controlled by phytoplankton availability. The mean $( \pm \mathrm{SE})$ deficits of chlorophyll $a$ and POC concentrations are 44 $\pm 4 \%$ and $26 \pm 9 \%$ respectively in the shellfish farming zone. The nutrient excess in shellfish farming zones was highly significant with increases of $73 \pm 16,36 \pm 12$ and $19 \pm 8 \%$ for ammonia, phosphates and silicate respectively. During summer, filter feeders are not food limited by the regenerated primary production, which is strongly increased by enhanced benthic nutrient fluxes.

Acknowledgements. The authors are grateful to C. Juge for drawing the figures. They thank S. Razouls for the loan of the $\mathrm{CHN}$ and anonymous reviewers for their comments on the manuscript. This work is a contribution of the Oxythau project from the 'Programme National d'Océanographie Côtière' and was funded by IFREMER and the 'Conseil Général' of Hérault. This is a study by the working group URM IFREMER-CNRS-Université Montpellier II No. 5.

\section{LITERATURE CITED}

Aminot A (1983) Dosage de l'oxygène dissous. In: Aminot A, Chaussepied M (eds) Manuel des analyses chimiques en milieu marin, Chap 5, CNEXO, Brest, p 75-92

Bacher C, Millet B, Vaquer A (1997) Modélisation de l'impact des mollusques cultivés sur la biomasse phytoplanctonique de l'étang de Thau (France). C R Acad Sci Paris 320:73-81

Barranguet C, Alliot E, Plante-Cuny MR (1994) Benthic microphytic activity at two Mediterranean shellfish cultivation sites with reference to benthic fluxes. Oceanol Acta $17: 211-221$

Bayne BL, Scullard C (1977) Rates of nitrogen excretion by species of Mytilus (Bivalvia: Mollusca). J Mar Biol Assoc UK 57:355-369

Chrétiennot-Dinet MJ, Courties C, Vaquer A, Neveux J, Claustre H, Lautier J, Machado MC (1995) A new marine picoeukaryote: Ostreococcus tauri gen. et sp. nov. (Chlorophyta, Prasinophyceae). Phycologia 34:285-292

Copin-Montégut C, Copin-Montégut G (1983) Stoichiometry of carbon, nitrogen, and phosphorus in marine particulate matter. Deep-Sea Res 30:31-46

Courties C, Vaquer A, Troussellier M, Lautier J, ChrétiennotDinet MJ, Neveux J, Machado C, Claustre H (1994) Smallest eukaryotic organism. Nature 370:255

Courties C, Perasso R, Chrétiennot-Dinet MJ, Gouy M, Guillou L, Troussellier M (1998) Phylogenetic analysis and genome size of Ostreococcus tauri (Chlorophyta, Prasinophyceae). J Phycol 34:844-849
Dame RF, Wolaver TG, Libes SM (1985) The summer uptake and release of nitrogen by an intertidal oyster reef. Neth J Sea Res 19:265-268

Dame RF, Spurrier JD, Wolaver TG (1989) Carbon, nitrogen and phosphorus processing by an oyster reef. Mar Ecol Prog Ser 54:249-256

David A (1971) Relations trophiques entre le plancton, les huîtres d'élevage et les ciones, épibiontes (étang de Thau). Bull Inst Peches Marit 201:1-15

Denis L, Grenz C, Plante-Cuny MR (1996) Etude expérimentale de la remise en suspension du microphytobenthos. C R Acad Sci Paris 319:529-535

Deslous-Paoli JM, Lannou AM, Geairon P, Bougrier S, Raillard O, Heral M (1992) Effects of the feeding behaviour of Crassostrea gigas (bivalve, mollusc) on biosedimentation of natural particulate matter. Hydrobiologia 231:85-91

Falkowski PG (1981) Light-shade adaptation and assimilation numbers. J Plankton Res 3:203-216

Fleury PG, Ruelle F, Claude S, Palvadeau H, Robert S, d'Amico F, Vercelli C, Chabirand JM (1999) Réseau de suivi de la croissance de l'huître creuse sur les côtes françaises. Rapport DRV/RA/RST/99-03, IFREMER, Sète (in French)

Furnas MJ (1990) In situ growth rates of marine phytoplankton: approaches to measurement, community and species growth rates. J Plankton Res 12:1117-1151

Gasc A (1997) Etude de la production primaire régénérée dans un écosystème conchylicole: le bassin de Thau. Thèse de Doctorat, Université de Montpellier II (in French)

Gerbal M, Verlaque M (1995) Macrophytobenthos de substrat meuble de l'étang de Thau (France, Méditerranée) et facteurs environnementaux associés. Oceanol Acta 18: $557-571$

Gilbert F, Souchu P, Bianchi M, Bonin P (1997) Influence of shellfish farming activities on nitrification, nitrate reduction to ammonium and denitrification at the water-sediment interface of Thau lagoon, France. Mar Ecol Prog Ser 151:143-153

Hawkins AJS, Bayne BL (1985) Seasonal variation in the relative utilization of carbon and nitrogen by the mussel Mytilus edulis: budgets, conversion efficiencies and maintenance requirements. Mar Ecol Prog Ser 25:181-188

Héral M, Deslous-Paoli JM, Sornin JM (1983) Transferts énergétiques entre l'huître Crassostrea gigas et la nourriture potentielle disponible dans un bassin ostréicole: premières approches. Oceanis 9:169-194

Holm-Hansen O, Lorenzen CJ, Holmes RW, Strickland JDH (1965) Fluorimetric determination of chlorophyll. J Cons Perm Int Explor Mer 30:3-15

Jarry V, Fiala M, Frisoni GF, Jacques G, Neveux J, Panouse M (1990) The spatial distribution of phytoplankton in a Mediterranean lagoon (Étang de Thau). Oceanol Acta 13: $503-512$

Jordan T, Valiela I (1982) A nitrogen budget of the ribbed mussel, Geukensia demissa, and its significance in nitrogen flow in a New England salt marsh. Limnol Oceanogr 27:75-90

Kaspar HF, Gillespie PA, Boyer IC, MacKenzie AL (1985) Effects of mussel aquaculture on the nitrogen cycle and benthic communities in Kenepuru Sound, Marlborough Sound, New Zealand. Mar Biol 85:127-136

Kautsky N, Evans S (1987) Role of biodeposition by Mytilus edulis in the circulation of matter and nutrients in a Baltic coastal ecosystem. Mar Ecol Prog Ser 38:201-212

Kautsky N, Wallentinus I (1980) Nutrient release from a Baltic Mytilus-red algal community and its role in benthic and pelagic productivity. Ophelia 1 (Suppl):17-30 
Kim YS (1983) A nitrogen budget of the farming oysters, Crassostrea gigas, in Geoje-Hansan Bay near Chungmu. Bull Tongyeong Fish Jr Coll 18:39-42

Koroleff F (1976) Determination of nutrients. In: Grasshoff K (ed) Methods of seawater analysis. Verlag Chemie, Weinheim, p 117-182

Kuenzler EJ (1961) Phosphorus budget of a mussel population. Limnol Oceanogr 6:400-415

Lam Hoai T, Rougier C, Lasserre G (1997) Tintinnids and rotifers in a northern Mediterranean coastal lagoon. Structural diversity and function through biomass estimations. Mar Ecol Prog Ser 152:13-25

Le Bec C, Mazurie J (1992) Croissance de Crassostrea gigas en Bretagne en 1989, mise en place d'un réseau d'acquisition des données. In: Le Pennec M (ed) Les mollusques marins: biologie et aquaculture. Actes Colloq Ifremer 14: 61-70

Mazouni N, Gaertner JC, Deslous-Paoli JM, Landrein S, Geringer d'Oedenberg M (1996) Nutrient and oxygen exchanges at the water-sediment interface in a shellfish farming lagoon (Thau, France). J Exp Mar Biol Ecol 205: 91-113

Mazouni N, Deslous-Paoli JM, Landrein S (1998a) Influence d'un élevage ostréicole sur les flux de nutriments et d'oxygène dans un écosystème lagunaire. Oceanol Acta 21:845-858

Mazouni N, Gaertner JC, Deslous-Paoli JM (1998b) Influence of oyster culture on water column characteristics in a coastal lagoon (Thau, France). Hydrobiologia 373/374: $149-156$

Millet B (1989) Fonctionnement hydrodynamique du bassin de Thau. Validation d'un modèle numérique de circulation (Programme ECOTHAU). Oceanol Acta 12:37-46

Millet B, Cecchi P (1992) Wind-induced hydrodynamic control of the phytoplankton biomass in a lagoon ecosystem. Limnol Oceanogr 37:140-146

Picot B, Péna G, Casellas C, Bondon D, Bontoux J (1990) Interpretation of the seasonal variations of nutrients in a Mediterranean lagoon: Étang de Thau. Hydrobiologia 207:105-114

Prins TC, Smaal AC (1994) The role of the blue mussel Mytilus edulis in the cycling of nutrients in the Oosterschelde estuary (The Netherlands). Hydrobiologia 282/ 283:413-429

Prins T, Smaal A, Dame R (1998) A review of the feedbacks between grazing and ecosystem processes. Aquat Ecol 31: 349-359

Editorial responsibility: Otto Kinne (Editor), Oldendorf/Luhe, Germany
Riemann B, Jensen LM (1991) Measurements of phytoplankton primary production by means of the acidification and bubbling method. J Plankton Res 13:853-862

Rodhouse PG, Roden CM (1987) Carbon budget for a coastal inlet in relation to intensive cultivation of suspensionfeeding bivalve molluscs. Mar Ecol Prog Ser 36:225-236

Smaal AC, Haas HA (1997) Seston dynamics and food availability on mussel and cockle beds. Estuar Coast Shelf Sci 45:247-259

Sornin JM, Feuillet M, Héral M, Fardeau JC (1986) Influence des cultures d'huitres Crassostrea gigas sur le cycle du phosphore en zone intertidale: rôle de la biodeposition. Oceanol Acta 9:313-322

Sornin JM, Collos Y, Delmas D, Feuillet-Girard M, Gouleau D (1990) Nitrogenous nutrient transfers in oyster ponds: role of sediment in deferred primary production. Mar Ecol Prog Ser 68:15-22

Souchu P, Mayzaud P, Roy S (1991) Environnement physicochimique et trophique d'un site myticole, Iles-de-laMadeleine (Québec). I. Evolution estivale des composés de l'azote, du phosphore et du silicium. In: Therriault JC (ed) Le golfe du Saint-Laurent: petit océan ou grand estuaire? Publ Spec Can Sci Halieut Aquat 113:209-218

Souchu P, Gasc A, Cahet G, Vaquer A, Collos Y, Deslous-Paoli JM (1997) Biogeochemical composition of Mediterranean waters outside Thau lagoon. Estuar Coast Shelf Sci 44: 275-284

Souchu P, Gasc A, Vaquer A, Collos Y, Tournier H, DeslousPaoli JM (1998) Biogeochemical aspects of bottom anoxia in a Mediterranean lagoon. Mar Ecol Prog Ser 164: $135-146$

Steemann-Nielsen E (1952) The use of radioactive carbon $\left({ }^{14} \mathrm{C}\right)$ for measuring organic production in the sea. J Cons Int Explor Mer 18:117-140

Tournier H, Pichot Y (1985) Répartition de la chlorophylle a dans l'étang de Thau: richesse nutritive pour les mollusques d'élevage. Rev Trav Inst Peches Marit 49:13-24

Tréguer P, Le Corre P (1975) Manuel d'analyse des sels nutritifs dans l'eau de mer. Utilisation de l'auto analyseur II, Technicon. L.O.C. Univ. Bretagne Occidentale, Brest

Vaquer A, Troussellier M, Courties C, Bibent B (1996) Standing stock and dynamics of picophytoplankton in Thau lagoon (northwest Mediterranean coast). Limnol Oceanogr 41:1821-1828

Ward BB (1985) Light and substrate concentration relationships with marine ammonium assimilation and oxidation rates. Mar Chem 16:301-316

Submitted: August 2, 2000; Accepted: December 12, 2000 Proofs received from author(s): August 2, 2001 